\title{
FINANCIAL VALUE, STRATEGIC VALUE AND MACROECONOMIC VALUE BANK SHARIAH DI INDONESIA
}

\author{
Fitri Laela Wijayati dan Dita Melinda \\ IAIN Surakarta \\ fitriwijayati@gmail.com
}

\begin{abstract}
The purpose of this study is to indentified drivers that have relationship with performance value in Indonesian Sharia Bank as an alternative to measure syariah bank performace. This study try to gived an alternative measurement sharia bank's performance based on internal aspect and eksternal aspect which are may haved been relationship in sharia bank performance. The sample of this study is Indonesian sharia bank which used panel data in periode 2010-2015. This study found there is relationship between financial,strategic value and macroeconomy have relationship to sharia bank performance and only zakat Performance ratio and Sohibul Maal Welfare Ratio have significant relationship with sharia bank performance
\end{abstract}

Keywords: performance value, sharia bank, financial value, strategic value, macroeconomic

\section{A. Pendahuluan}

Perkembangan perbankan syariah di Indonesia mengalami peningkatan secara singnifikan selama 3 dekade terakhir, berdasarkan laporan statistik yang dilansir oleh Otoritas Jasa Keuangan (OJK) bulan Juni 2015 menunjukkan jumlah bank syariah di Indonesia yang berbentuk Bank Umum Syariah (BUS) berjumlah 12 dan dalam bentuk Unit Usaha Syariah (UUS) berjumlah 22 sedangkan untuk Bank Pembiayaan Rakyat Syariah (BPRS) berjumlah 16 .

Pada perkembangannya, industri perbankan syariah cukup mendapatkan tempat pada sektor industri keuangan secara global 
walaupun dengan presentase yang kecil. Perhatian masyarakat global mulai bergeser kepada perbankan syariah, dimana sektor perbankan syariah mampu memberikan kontribusi pada ketahanan ekonomi global dengan pengelolaan mekanisme perbankan berdasarkan prinsip- prinsip syariah. Pergeseran perhatian masyarakat global terhadap perbankan syariah berdasarkan fenomena global dimana perbankan syariah mampu bertahan dalam menghadapi krisis keuangan global.

Pergeseran perhatian masyarakat membawa tantangan tersendiri bagi perbankan syariah untuk meningkatkan kinerjanya dalam rangka meraih kepercayaan para stakeholders. Kepercayaan stakeholders merupakan aspek utama bagi perbankan syariah dalam rangka untuk menghimpun dana masyarakat melalui kegiatan investasi, simpanan maupun kegiatan pembiayaan sesuai dengan kaidah-kaidah syariah. Menurut Chapra \& Ahmad (2002), stakeholders utama dari bank syariah adalah Islam itu sendiri. Penerapan kaidah/prinsip syariah dalam perbankan syariah membawa harapan para stakeholders kepada mekanisme tata kelola perbankan syariah dalam rangka meningkatkan kinerja perbankan syariah untuk mencapai kesejahteraan finansial dan kesejahteraan sosial. Hal ini beararti bank syariah harus menajga citra Islam dimata para stakeholders.

Terdapat beberapa ketentuan yang harus dipenuhi oleh sektor perbankan syariah dalam menjalankan kegiatan usahanya. Peraturan Bank Indonesia nomor 13/23/PBI/2011 tentang penerapan manajemen risiko bagi bank umum syariah dan unit usaha syariah dengan mengatur mengenai penerapan manajemen risiko bagi BUS dan UUS untuk mengidentifikasi, mengukur dan mengendalikan resiko yang mungki dihadapi oleh perbankan syariah. Peraturan Bank Indonesia Nomor 14/18/ PBI/2012 tentang Kewajiban Penyediaan Modal Minimum yang harus dipenuhi oleh perbankan syariah dalam rangka memenuhi kemampuan likuiditasnya.

Berdasarkan serangkaian peraturan yang mengatur tata pengelolaan bank syariah diharapkan mampu untuk meningkatkan kinerja sektor perbankan syariah. Peningkatan kinerja pada perbankan syariah merupakan salah satu aspek yang 
penting yang harus dipenuhi untuk kepentingan para stakeholders baik kepentingan masyarakat maupun untuk kepentingan regulasi/ regulator.

Perlunya indentifikasi faktor-faktor internal dan eksternal yang mempengaruhi kinerja bank syariah sangatlah penting. Faktor internal dapat diindentifikasi berdasarkan financial valeu dan strategic value yang diterapkan (Tiwari, 2015). Dalam penilaian mengenai kinerja bank syariah tentunya tidak dapat dipisahkan dengan kondisi makro ekonomi negara dimana kinerja bank syariah sangat sensitif dengan kondisi makro ekonomi (Al Kayed et al, 2014).

Al Kayed et al (2014) menguji mengenai hubungan struktur permodalan bank syariah dengan kinerja bank syariah sebagai alternatif bagi para manajer untuk meningkatkan struktur pendanaan pada bank syariah. Al-Kayed et al (2014) menggunakan rasio permodalan untuk menguji kinerja bank syariah yang diproksikan dengan menggunakan ROE (Return on Equity), ROA (return on asset), BTP/TA (profit margin) dan NIM (non interest margin) dan mengendalikan faktor makro ekonomi, struktur keuangan, perpajakan, local markets, dan periode waktu. Hasil penelitian menunjukkan bahwa profitabilitas perusahaan berhubungan positif dengan peningkatan permodalan.

Siddiqui (2008) meneliti mengenai kontrak keuangan, resiko terhadap kinerja bank syariah. Kebutuhan untuk memenuhi kecukupan modal yang ditetapkan oleh regulator menuntut sektor perbankan syariah untuk memenuhi kecukupan modal minimum bank. Kecukupan modal minimum tersebut digunakan untuk menjaga likuiditas bank dan digunakna sebagai dasar penambahan modal bagi bank syariah. Berdasarkan hal tersebut, siddiqui (2008) mencoba untuk memberikan alternatif mengenai instrumen untuk memanajemen risiko dan likuiditas bank syariah untuk memberikan gambaran kepada manajer untuk meingkatkan kinerja keuangannya dan sebagai dasar bagi skateholders untuk menempatkan modalnya pada sektor perbankan syariah.

Pellegrina (2015) mencoba untuk menginvestigasi dampak dari kapitalisasi modal pada kemampuan untuk mengambil resiko 
(risk taking eficiency)pada bank syariah dan bank konvensional. Penelitian tersebut didasarkan pada fenomena bahwa terdapat perdebatan mengenai kebutuhan kecukupan modal yang disyaratkan oleh regulator dan dampaknya terhadap profitabilitas perbankan. Hasil penelitian tersebut menunjukkan penerapan strategi pada bank syariah berbeda dengan yang dilakukan oleh bank syariah dengan semakin tinggi tingkat kapitalisiasi berhubungan dengan penurunan resiko struktur aset pada bank syariah.

Berdasarkan penjabaran di atas, dalam rangka menciptakan value pada bank syariah diperlukan indentifikasi mengenai kinerja bank syariah yang dapat diidentifikasi berdasarkan financial value, strategic value dan makro ekonomi. Indentifikasi tersebut membantu para manajer untuk menemukan keunikan dalam perusahaan yang dapat digunakan untuk mencapai keunggulan kompetitif perusahaan sehingga menarik para stakeholder untuk menempatkan dananya pada sektor ini yang berorientasi pada penciptaan nilai maksimum para stakeholder.

\section{B. Tinjauan Pustaka}

\section{Teori Sinyal (Signaling Theory)}

Teori signal didasarkan pada kebutuhan informasi bagi para stakeholder. Informasi yang dipublikasikan akan memberikan signal kepada para stakeholders untuk proses pengambilan keputusan investasi (Jogiyanto, 2000). Informasi tersebut dapat dianggap sebagai informasi baik (good news) maupun sebagai informasi buruk (bad news) tergantung pada analisis dan intepretasi dari stakeholders. Informasi dianggap sebagai informasi yang berguna jika ketersediaan informasi tersebut dapat memberikan nilai tambah bagi stakeholders dan mempengaruhi keputusan stakeholders dalam menempatkan dana mereka pada sebuha pilihan investasi. Ketersediaan informasi sering pula tergantung kepada kemauan manajer selaku pengelola perusahaan untuk mengungkapkan informasi yang bermanfaat bagi para stakeholders.

Teori sinyal menuntut manajer atau pengelola perusahaan untuk menyediakan informasi yang memadai mengenai keuangan perusahaan. Salah satu bentuk informasi keuangan perusahaan 
dapat berupa laporan tahunan yang diterbitkan perusahaan sebagai salah bentuk pertanggung jawaban kepada para stakeholder.. Laporan tahunan perusahaan yang diterbitkan tersebut diharapkan dapat memberikan signal ataupun informasi yang berguna bagi para stakeholder untuk mengambil keputusan yang berkaitan dengan kegiatan pendaaan yang dilakukan oleh perusahaan. Mengingat keterbatas sumber pendanaan perusahaan, maka informasi yang disajikan dalam laporan tahunan perushaan harus memuat keunggulan-keuungulan atau daya saing perusahaan sehingga dapat menarik minat stakeholders untuk menempatkan dana mereka. Para stakeholder menggunakan informasi tersebut untuk menganalisisi resiko dan untuk membuat pilihan diservikasi penempatan dana investasi yang diinginkan oleh stakeholders.

\section{Kinerja Bank Shariah}

Dalam rangka meningkatkan kinerjanya, perbankan syariah harus mampu untuk mengidentifikasi faktor-faktor yang mempengaruhi kinerja perbankan syariah. Menurut Tiwari (2015), drivers dapat digunakan untuk menciptakan nilai bagi perusahaan dengan menemukan keunikan-keunikan sebagai penciri perusahaan melalui proses indentifikasi drivers yang yang berpengaruh terhadap peningkatan nilai bagi para stakeholders. Penciptaan nilai bagi stakehorders sangtlah penting dalam rangka untuk penghimpunan dana bagi perusahaan. Ketepatan proses identifikasi drivers akan memberikan keuntungan bagi perusahaan untuk memetakkan nilai-nilai keunggulan yang dapat meningkatkan kesan dan harapan bagi para stakeholders terhadap perusahaan. Tiwari (2015) mengembangkan konsep drivers of firms value kedalam dua konsep utama yaitu financial value drivers dan strategic value drivers dengan masing-masing klasifikasi indikator untuk mengukur kedua konsep drivers tersebut. Klasifikasi kedua konsep tersebut dilakukan untuk mengidentifikasi drivers performace perusahaan dalam rangka menciptakan nilai bagi perusahaan.

Tidak dipungkiri bahwa struktur pendanaan merupakan salah satu drivers penting dalam perbankan syariah. Kemampuan untuk memenuhi kecukupan modal minimal bagi perbankan sesuai dengan yang disyaratkan regulator merupakan salah atu faktor 
utama yang mempengaruhi kinerja bank syariah. Al Kayed et al (2014) menguji mengenai hubungan struktur permodalan bank syariah dengan kinerja bank syariah sebagai alternatif bagi para manajer untuk meningkatkan struktur pendanaan pada bank syariah. AlKayed et al (2014) menggunakan rasio permodalan untuk menguji kinerja bank syariah yang diproksikan dengan menggunakan ROE (Return on Equity), ROA (return on asset), BTP/TA (profit margin) dan NIM (non interest margin) dan mengendalikan faktor makro ekonomi, struktur keuangan, perpajakan, local markets, dan periode waktu. Hasil penelitian menunjukkan bahwa profitabilitas perusahaan berhubungan positif dengan peningkatan permodalan. Pellegrina (2015) mencoba untuk menginvestigasi dampak dari kapitalisasi modal pada kemampuan untuk mengambil resiko (risk taking eficiency)pada bank syariah dan bank konvensional. Penelitian tersebut didasarkan pada fenomena bahwa terdapat perdebatan mengenai kebutuhan kecukupan modal yang disyaratkan oleh regulator dan dampaknya terhadap profitabilitas perbankan. Hasil penelitian tersebut menunjukkan penerapan strategi pada bank syariah berbeda dengan yang dilakukan oleh bank syariah dengan semakin tinggi tingkat kapitalisiasi berhubungan dengan penurunan resiko struktur aset pada bank syariah.

Cheremnikh (2000) dalam Kazlauskiene and Christauskas (2008) menawarkan konsep pengembangan value bagi perusahaan dengan mengklasifikasikan drivers ke dalam 2 kategori yaitu: drivers internal dan drivers eksternal; dan kuantitatif dan kualitatif drivers. Drivers internal berkaitan dengan faktor internal mengenai kinerja perusahaan dan drivers eksternal berkaitan dengan kondisi makro ekonomi yang mempengaruhi perusahaan. kuantitatif drivers berkaitan dengan pengumpulan dan analisis data dalam bentuk angka sedangkan kualitatif drivers merujuk pada deksripsi mengenai kualitas atau karaketristik perushaan. Kedua kategori diatas merupakan satu kesatuan drivers yang mempengaruhi kinerja pada perusahaan, hal ini pula dapat diterapkan untuk mengidentifikasi drivers performance pada bank syariah untuk menciptakan nilai bagi sektor tersebut. Aspek finansial, strategi dan makro ekonomi tidak dapat dipisahkan ketika kita membahas mengenai drivers performance value bagi bank syariah. Ketiga hal 
tersebut saling berkaitan dalam meningkatkan kinerja bank syariah dengan peran masing-masing. Aspek finasial dan aspek strategi perusahaan merupakan faktor internal yang berkaitan dengan kemapuan bank syariah dalam memanfaatkan sumber daya yang dimiliki untuk menjalankan kegiatan bisnisnya sesuai dengan tujuan utama bank syariah. Kedua aspek ini pun tidak dapat berjalan ketika spek makro ekonomi negara tidak berjalan dengan baik. Hal ini disebabkan karena aspek makro ekonomi merupakan acuan bagi bank dalam menjalankan kegiatan bisnisnya karena tidak dapat dipungkiri bahwa kondisi makro eknomi dalam suatu negara dapat berdampak pada kegiatan usaha sektor tesebut.

\section{Drivers Performance Value Sharia Bank dan Sharia Bank Performance}

Pada pembahasan sebelumnya telah dijelaskan mengenai drivers performance sharia bank. Penelitian yang dilakukan oleh Tiwari (2015) mendeskripsikan drivers perfrmance pada industri manufaktur ke dalam dua drivers utama yaitu financial value drivers dan strategic value drivers. Financial value drivers ini berhubungan dengan nilai- nilai yang dapat diidentifikasi berdasarkan faktorfaktor pemicu (drivers) dari kinerja keuangan perbankan shariah. Ketepatan pengidentifikasian financial value drivers dapat membantu untuk meningkatkan nilai intrinsik perusahaan karena drivers ini berhubungan langsung dengan kinerja keuangan perusahaan. Startegic value drivers ini berhubungan dengan nilai-nilai strategik yang diambil oleh perusahaan dalam rangka untuk meningkatkan kinerja perbankan shariah. Nilai strategik ini berhubungan dengan Strategic value drivers ini merupakan langkah yang dipilih perusahaan dalam rangka membangun dan mengembangkan perusahaan dengan serangkai kebijakan yang diambil oleh manajemen dalam rangka menciptakan nilai atau persepsi bagi para investor. Ketepatan strategi yang diambil oleh perusahaan pada akhirnya akan berdampak pada penciptaan nilai perusahaan dan sebagai faktor unggulan atau penciri perusahaan yang berbeda dengan perusahaan lain yang sejenis pada akhirnya hal tersebut akan meningkatkan nilai bagi perusahaan sehingga dapat 
meningkatkan harapan investor kepada perusahaan menuju ke arah perkembangan yang baik.

Aspek makro ekonomi merupakan hal yang penting untuk melihat faktor pemicu (drivers) pada kinerja perbankan shariah. Tidak dipungkiri bahwa perbankan shariah sangat sensitif terhadap laju kondisi makro ekonomi. Beberapa penelitian mengemukakan bahwa aspek makro ekonomi memiliki peranan peting bagi sektor perbankan termasuk pada sektor perbankan shariah. Kabid dan Hameed (2003) dalam Al Kayed (2014) mengemukakan bahwa aspek makro ekonomi memiliki peranan penting sebagai faktor kendali untuk menilai profitabilitas bank shariah. Kegiatan makro ekonomi yang dilakukan oleh suatu negara akan berdampak pada kebijakan yang diambil oleh pemerintah dalam hal ini kebiajakan yang berkaitan dengan kebijakan moneter yang diambil. Kebijakan moneter yang diambil oleh pemerintah akan berdampak pada laju perkembangan perbankan pada umumnya sehingga kinerja bank shariah akan sensitif terhadap laju perkembangan makro okonomi suatu negara (Al Kayed et al, 2014). faktor makro ekonomi perlu untuk diidentifikasi untuk mengevaluasi kinerja pada perbankan shariah.

Hipotesis yang dapat dirumuskan berdasar dari uraian teori dan hasil penelitian-penelitian terdahulu dalam penelitian ini adalah sebagai berikut:
$\mathbf{H}_{1}=$ terdapat hubungan antara finacial value drivers dengan performace value bank syariah
$\mathbf{H}_{2}=$ terdapat hubungan antara strategic value drivers dengan performace value bank syariah
$\mathrm{H}_{3}=$ terdapat hubungan antara macroeconomic drivers dengan performace value bank syariah

\section{Metode Penelitian}

Dalam penelitian mencoba untuk meneliti mengenai finacial value drivers, strategic value drivers dan makro economi drivers untuk mengidentifikasi kinerja bank shariah di Indoensia periode 2010-2015. 


\section{Pengumpulan Data dan Pemilihan Sampel}

Penelitian ini menggunakan sampel bank syariah di Indonesia yang terdiri atas bank Syariah Umum (BUS) dan Unit Usaha syariah (UUS) yang melaporkan laporan keuangan triwulanan secara runtut waktu selama tahun 2010-2015. Penelitian ini menggunkan data panel bank syariah yang melaporkan laporan keuangan interim dan dievaluasi oleh Otoritas Jasa Keuangan (OJK) setiap 3 bulan sekali. Kriteria sampel pada penelitian ini adalah:

a. Secara rutin melaporkan laporan keuangan selama periode 2010-2015

b. Tidak atau sedang mendapatkan sangsi dari otoritas terkait yaitu OJK dan Bank Indonesia

c. Memiliki data yang lengkap yang dibutuhkan dalam penelitian ini.

d. Total sampel dalam penelitian ini diperoleh 240 sampel.

\section{Definisi Operasional dan Pengukuran Variabel}

Berikut ini merupakan definisi operasional dari setiap variabel beserta instrumen pengukuran dari masing-masing variabel. Penelitian ini mencoba mengidentifikasi faktor-faktor pemicu kinerja (drivers perfonce) bank syariah ke dalam tiga (3) katergori yaitu: financial value drivers, strategic value drivers dan macroeconomic drivers.

\section{a. Financial value drivers}

Financial value drivers ini berhubungan dengan nilai- nilai yang dapat diidentifikasi berdasarkan faktor-faktor pemicu (drivers) dari kinerja keuangan perbankan shariah. Ketepatan pengidentifikasian financial value drivers dapat membantu untuk meningkatkan nilai intrinsik perusahaan karena drivers ini berhubungan langsung dengan kinerja keuangan perusahaan. Nilai intrinsik perusahaan merupakan hal yang menjadi bagian utama bagi para stakeholders utamanya bagi para investor karena nilai ini dapat menciptakan nilai perusahaan yang pada akhirnya dapat menciptakan nilai bagi investor. 


\section{b. Strategic value drivers}

Startegic value drivers ini berhubungan dengan nilainilai strategik yang diambil oleh perusahaan dalam rangka untuk meningkatkan kinerja perbankan shariah. Nilai strategik ini berhubungan dengan Strategic value drivers ini merupakan langkah yang dipilih perusahaan dalam rangka membangun dan mengembangkan perusahaan dengan serangkai kebijakan yang diambil oleh manajemen dalam rangka menciptakan nilai atau persepsi bagi para investor. Ketepatan strategi yang diambil oleh perusahaan pada akhirnya akan berdampak pada penciptaan nilai perusahaan dan sebagai faktor unggulan atau penciri perusahaan yang berbeda dengan perusahaan lain yang sejenis pada akhirnya hal tersebut akan meningkatkan nilai bagi perushaan sehingga dapat meningkatkan harapan investor kepada perusahaan menuju ke arah perkembangan yang baik.

\section{c. Macro economic drivers}

Aspek makro ekonomi merupakan hal yang penting untuk melihat faktor pemicu (drivers) pada kinerja perbankan shariah. Tidak dipungkiri bahwa perbankan shariah sangat sensitif terhadap laju kondisi makro ekonomi. Kegiatan makro ekonomi yang dilakukan oleh suatu negara akan berdampak pada kebijakan yang diambil oleh pemerintah dalam hal ini kebiajakan yang berkaitan dengan kebijakan moneter yang diambil. Kebijakan moneter yang diambil oleh pemerintah akan berdampak pada laju perkembangan perbankan pada umumnya sehingga kinerja bank shariah akan sensitif terhadap laju perkembangan makro okonomi suatu negara. faktor makro ekonomi perlu untuk diidentifikasi untuk mengevaluasi kinerja pada perbankan shariah. 
Financial Value, Strategic Value And Macroeconomic Value ...

Berikut disajikan definisi operasional beserta indikator pengukuran dari masing-masing drivers yang tersaji pada tabel 1

\begin{tabular}{|c|c|c|c|}
\hline Variabel & Indikator & Pengukuran & Deskripsi \\
\hline \multirow{5}{*}{$\begin{array}{c}\text { Performance } \\
\text { value }\end{array}$} & ROE & $\begin{array}{l}\text { Laba bersih } \\
\text { setelah pajak } \\
\text { dibagi dengan } \\
\text { rata-rata modal } \\
\text { disetor }\end{array}$ & $\begin{array}{l}\text { Mengukur } \\
\text { kemampuan modal } \\
\text { disetor bank dalam } \\
\text { menghasilkan laba. }\end{array}$ \\
\hline & ROA & $\begin{array}{c}\text { Laba bersih setela } \\
\text { pajak dibagi } \\
\text { dengan rata-rata } \\
\text { total aset } \\
\end{array}$ & $\begin{array}{c}\text { Mengukur } \\
\text { keberhasilan } \\
\text { manajemen dalam } \\
\text { menghasilkan laba. }\end{array}$ \\
\hline & $\mathrm{BTP} / \mathrm{TA}$ & $\begin{array}{c}\text { Laba bersih } \\
\text { sebelum pajak } \\
\text { dibagi dengan } \\
\text { total aset } \\
\end{array}$ & $\begin{array}{l}\text { Untuk mengukur } \\
\text { laba margin dalam } \\
\text { menghasilkan laba. }\end{array}$ \\
\hline & NPF & $\begin{array}{c}\text { Pembiayaan KL, } \\
\text { D dan M dibagi } \\
\text { dengan total } \\
\text { pembiayaan }\end{array}$ & $\begin{array}{c}\text { Mengukur tingkat } \\
\text { permasalahan } \\
\text { Pembiayaan yang } \\
\text { dihadapi oleh bank. }\end{array}$ \\
\hline & REO & $\begin{array}{c}\text { Biaya operasional } \\
\text { dibagi total } \\
\text { pendapatan }\end{array}$ & $\begin{array}{c}\text { Mengukur efisiensi } \\
\text { kegiatan operasional } \\
\text { bank syariah. }\end{array}$ \\
\hline \multirow{5}{*}{$\begin{array}{l}\text { Financial } \\
\text { drivers }\end{array}$} & $\begin{array}{l}\text { Profit sharing } \\
\text { ratio }\end{array}$ & $\begin{array}{c}\text { Mudharabah } \\
+ \text { musyarakah } \\
\text { dibagi dengan } \\
\text { total pendanaan }\end{array}$ & $\begin{array}{l}\text { Mengukur besarnya } \\
\text { fungsi intermediasi } \\
\text { bank syariah dengan } \\
\text { akad profit sharing. }\end{array}$ \\
\hline & $\begin{array}{l}\text { Zakat } \\
\text { performace } \\
\text { ratio }\end{array}$ & $\begin{array}{l}\text { Penyaluran zakat } \\
\text { perusahaan dibagi } \\
\text { dengan laba } \\
\text { sebelum pajak }\end{array}$ & $\begin{array}{c}\text { Mengukur besarnya } \\
\text { kontribusi zakat } \\
\text { perusahaan bank } \\
\text { syariah. }\end{array}$ \\
\hline & $\begin{array}{l}\text { Equitable } \\
\text { distribution } \\
\text { ratio }\end{array}$ & $\begin{array}{c}\text { Bagian laba } \\
\text { investor dibagi } \\
\text { dengan laba } \\
\text { bersih } \\
\end{array}$ & $\begin{array}{c}\text { Mengukur } \\
\text { besarnya kontribusi } \\
\text { penyaluran laba bagi } \\
\text { investor } \\
\end{array}$ \\
\hline & $\mathrm{KAP}$ & $\begin{array}{c}1 \text { dikurangi } \\
\text { (APYD (DPK, } \\
\text { KL, D, M) dibagi } \\
\text { aktiva produktif) }\end{array}$ & $\begin{array}{l}\text { Mengukur kualitas } \\
\text { aktiva produktif bank } \\
\text { syariah }\end{array}$ \\
\hline & $\begin{array}{l}\text { Agency } \\
\text { shariah bank } \\
\text { ratio }\end{array}$ & $\begin{array}{c}\text { DPK profit } \\
\text { sharing dibagi } \\
\text { dengan total DPK }\end{array}$ & $\begin{array}{l}\text { Mengukur besarnya } \\
\text { fungsi agency bank } \\
\text { syariah. }\end{array}$ \\
\hline
\end{tabular}




\begin{tabular}{|c|c|c|c|c|c|c|}
\hline \multirow{5}{*}{$\begin{array}{l}\text { Strategic } \\
\text { drivers }\end{array}$} & \multicolumn{2}{|c|}{$\begin{array}{l}\text { CR/ } \\
\text { capital } \\
\text { Ratio }\end{array}$} & \multicolumn{2}{|c|}{$\begin{array}{c}\text { Nilai buku ekuitas } \\
\text { shareholders } \\
\text { dibagi dengan total } \\
\text { aset }\end{array}$} & \multicolumn{2}{|c|}{$\begin{array}{l}\text { Mengukur besarnya } \\
\text { kemampuan pendanaan } \\
\text { shareholders }\end{array}$} \\
\hline & \multicolumn{2}{|c|}{$\begin{array}{c}\mathrm{R} \& \mathrm{D} \\
\text { ratio }\end{array}$} & \multicolumn{2}{|c|}{$\begin{array}{c}\text { Biaya riset dan } \\
\text { development } \\
\text { dibagi dengan laba } \\
\text { setelah pajak }\end{array}$} & \multicolumn{2}{|c|}{$\begin{array}{c}\text { Mengukur besarnya alokasi } \\
\text { dana untuk program } \\
\text { riset dan pengembangan } \\
\text { institusinya }\end{array}$} \\
\hline & \multicolumn{2}{|c|}{ CSR ratio } & \multicolumn{2}{|c|}{$\begin{array}{l}\text { Biaya promosi } \\
\text { dibagi dengan } \\
\text { biaya operasional }\end{array}$} & \multicolumn{2}{|c|}{$\begin{array}{l}\text { Mengukur besar fungsi } \\
\text { corporate social responsibility } \\
\text { (CSR) terhadap proses } \\
\text { pembelajaran masyarakat. }\end{array}$} \\
\hline & \multirow{2}{*}{\multicolumn{2}{|c|}{$\begin{array}{l}\text { Mudharib } \\
\text { Welfare } \\
\text { Ratio }\end{array}$}} & \multirow{2}{*}{\multicolumn{2}{|c|}{$\begin{array}{l}\text { Biaya gaji dan } \\
\text { kesejahteraan } \\
\text { dibagi dengan } \\
\text { total pendapatan } \\
\text { operasional }\end{array}$}} & \multirow{2}{*}{\multicolumn{2}{|c|}{$\begin{array}{c}\text { Mengukur besarnya } \\
\text { proporsi alokasi pendapatan } \\
\text { operasional bank syariah } \\
\text { yang dinikmati oleh } \\
\text { manajemen dan pegawai } \\
\text { dalam bentuk gaji dan } \\
\text { tunjangan lainnya }\end{array}$}} \\
\hline & & & & & & \\
\hline \multirow[t]{6}{*}{$\begin{array}{r}\text { Macroecon } \\
\text { diver }\end{array}$} & mics & \multicolumn{2}{|c|}{$\begin{array}{l}\text { Shohibull } \\
\text { Mall Welfare } \\
\text { ratio }\end{array}$} & \multicolumn{2}{|c|}{$\begin{array}{l}\text { Laba setelah pajak } \\
\text { dibagi dengan } \\
\text { modal inti (total } \\
\text { ekuitas) }\end{array}$} & $\begin{array}{c}\text { Mengukur } \\
\text { besarnya } \\
\text { keuntungan bank } \\
\text { syariah yang } \\
\text { dinikmati oleh } \\
\text { pemegang saham. }\end{array}$ \\
\hline & & \multicolumn{2}{|c|}{$\begin{array}{l}\text { GDP growth } \\
\text { rate }\end{array}$} & \multicolumn{2}{|c|}{$\begin{array}{c}\mathrm{GDP}=(\mathrm{GDPt} 1-1- \\
\mathrm{GDPt}) / \mathrm{GDPt}\end{array}$} & $\begin{array}{l}\text { Mengukur tingkat } \\
\text { pertumbuhan } \\
\text { GDP }\end{array}$ \\
\hline & \multicolumn{3}{|c|}{ Inflasi } & \multicolumn{2}{|c|}{$\begin{array}{c}\text { index }(\mathrm{CPI})= \\
(\mathrm{CPIt} 1-\mathrm{CPIt}) / \\
\text { CPIt }\end{array}$} & $\begin{array}{l}\text { Mengukur tingkat } \\
\text { inflasi }\end{array}$ \\
\hline & \multicolumn{3}{|c|}{ BNK ratio } & $\begin{array}{r}\text { Total as } \\
\text { deposit ba } \\
\text { dengar }\end{array}$ & $\begin{array}{l}\text { et dari } \\
\text { nk dibagi } \\
\text { GDP }\end{array}$ & $\begin{array}{c}\text { Mengukur } \\
\text { total aset yang } \\
\text { ditempatkan pada } \\
\text { deposito bank } \\
\end{array}$ \\
\hline & \multicolumn{3}{|c|}{$\begin{array}{l}\text { Herfindahl } \\
\text { index of } \\
\text { market } \\
\text { concentration }\end{array}$} & \multicolumn{2}{|c|}{$\begin{array}{l}\text { Penjumlahan } \\
\text { market share } \\
\text { seluruh bank } \\
\text { syariah }\end{array}$} & $\begin{array}{c}\text { Mengukur } \\
\text { market shart bank } \\
\text { syariah secara } \\
\text { keseluruhan }\end{array}$ \\
\hline & \multicolumn{3}{|c|}{$\begin{array}{l}\text { Bank Market } \\
\text { ratio }\end{array}$} & \multicolumn{2}{|c|}{$\begin{array}{c}\text { Total deposito } \\
\text { masing-masing } \\
\text { bank dibagi dengan } \\
\text { total deposito } \\
\text { diempatkan di } \\
\text { seluruh sektor } \\
\text { perbankan. }\end{array}$} & $\begin{array}{l}\text { Mengukur market } \\
\text { share per bank } \\
\text { syariah }\end{array}$ \\
\hline
\end{tabular}




\section{Metode Analisis Data}

Untuk menguji hipothesis dalam penelitian ini digunakan uji analisis korelas kanonikal yaitu alat analisisi yang idgunakan untuk menguji hubungan antara dua atau lebih variabel dependen dengan dua atau lebih variabel independen (ghozali, 2016).

Dalam m Analisis korelasi kanonikal ini membutuhkan uji asumsi klasik untuk meningkatkan korelasi antar variabel (ghozali 2016). Uji asumsi klasik yang digunakna adalah uji normalitas, uji mulitikolinieritas, uji autokorelasi dan uji herteroskedastisitas. Tahapan dalam uji korelasi kanonikal menurut Ghozali (2016) adalah:

1) Mendapatkan fungsi kanonikal dan menilai overall

2) Intepretasi kanonikal variate dengan melihat:

a. Canonical weight digunakan utntuk meliat tanda dan besarnya canonical weight untuk setiap variabel dalam kanonikal

b. Canonical loading digunakan untuk mengukur korelasi linier sederhana antara variabel origin dalam variabel dependen atau independen dan set canonical variate.

\section{D.Hasil Dan Pembahasan}

Data dalam penelitian ini menggunakan data sekunder yang bersumber pada laporan keuangan triwulanan bank syariah di Indonesia baik bank syariah yang berbentuk Bank Umum Syariah (BUS) dan Unit Usaha Syariah (UUS) selama tahun 2010-2015. Penelitian ini menggunakan sampel laporan keuangan triwulanan untuk melihat sensitifitas setiap indikator pada masing-masing drivers. Total sampel dalam penelitian ini adalah sebanyak 240 sampel yang terdiri atas 10 bank syariah.

\section{Uji Asumsi Klasik}

\section{a. Uji Multikolinieritas}

Uji multikolinearitas bertujuan untuk menguji apakah model regresi ditemukan adanya korelasi antar variabel bebas / independen (ghozali, 2016). Untuk mendeteksi ada tidaknya gejala 
multikolinearitas antar variabel independen digunakan uji variance inflation factor (VIF).

\section{b. Uji Multikolinieritas}

\begin{tabular}{|l|c|l|}
\hline Variabel & $\begin{array}{c}\text { Variance } \\
\text { inflation Factor } \\
\text { (VIF) }\end{array}$ & Keterangan \\
\hline PSR & 1,020 & Tidak terdapat multikolinieritas \\
ZPR & 1,095 & Tidak terdapat multikolinieritas \\
EDR & 1,106 & Tidak terdapat multikolinieritas \\
KAP & 1,049 & Tidak terdapat multikolinieritas \\
ASBR & 1,013 & Tidak terdapat multikolinieritas \\
CR & 1,375 & Tidak terdapat multikolinieritas \\
RND & 1,356 & Tidak terdapat multikolinieritas \\
CSR & 1,789 & Tidak terdapat multikolinieritas \\
MWR & 1,390 & Tidak terdapat multikolinieritas \\
SMWR & 1,086 & Tidak terdapat multikolinieritas \\
GDP & 1,293 & Tidak terdapat multikolinieritas \\
INF & 1,076 & Tidak terdapat multikolinieritas \\
BNK & 8,372 & Tidak terdapat multikolinieritas \\
BMR & 8,497 & Tidak terdapat multikolinieritas \\
\hline
\end{tabular}

Var dependen:ROA, ROE, BTPTA, NPF, REO

\section{c. Uji Autokorelasi}

Autokorelasi adalah korelasi antara anggota-anggota serangkaian observasi yang diurutkan menurut waktu (seperti dalam time series) atau ruang (Ghozali, 2016). Untuk mendeteksi adanya gejala autokorelasi digunakan durbin watson test

\begin{tabular}{|c|c|c|c|c|c|}
\hline \multicolumn{5}{|c|}{ Model Summary } \\
\hline Model & $\mathrm{R}$ & R Square & $\begin{array}{c}\text { Adjusted R } \\
\text { Square }\end{array}$ & $\begin{array}{c}\text { Std. Error of the } \\
\text { Estimate }\end{array}$ & $\begin{array}{c}\text { Durbin- } \\
\text { Watson }\end{array}$ \\
\hline 1 &, $926^{\mathrm{a}}$ &, 858 &, 849 &, 49470 & 1,875 \\
\hline
\end{tabular}

a) Predictors: (Constant), BMR,INF, KAP, EDR, CSR, CR, RN, ASBR, SMWR, GDP, BNK, MWR, PSR, ZPR

b) Dependent Variable: ROA

Berdasarkan kedua tabel di atas, nilai durbin watson untuk performance sebesar 1,875 diantara 4 -du $\leq \mathrm{d} \leq 4$-dl sehingga dapat disimpulkan bahwa tidak terdapat autokorelasi. 


\section{d. Uji heteroskedastisitas}

Heteroskedastisitas adalah terjadinya ketidaksamaan variance dari residual satu pengamatan ke pengamatan yang lain, untuk mendeteksi adanya heteroskedastisitas dilakukan dengan uji glejser (ghozali, 2016). Uji Glejser mengusulkan untuk meregresi nilai absolut residual terhadap variabel independen.

\section{e. Uji Heteroskedastisitas}

\begin{tabular}{|c|c|l|}
\hline Variabel & Signifikansi & \multicolumn{1}{|c|}{ Keterangan } \\
\hline PSR & 1,00 & Tidak terjadi heteroskedastisitas \\
ZPR & 1,00 & Tidak terjadi heteroskedastisitas \\
EDR & 1,00 & Tidak terjadi heteroskedastisitas \\
KAP & 1,00 & Tidak terjadi heteroskedastisitas \\
ASBR & 1,00 & Tidak terjadi heteroskedastisitas \\
CR & 1,00 & Tidak terjadi heteroskedastisitas \\
RND & 1,00 & Tidak terjadi heteroskedastisitas \\
CSR & 1,00 & Tidak terjadi heteroskedastisitas \\
MWR & 1,00 & Tidak terjadi heteroskedastisitas \\
SMWR & 1,00 & Tidak terjadi heteroskedastisitas \\
GDP & 1,00 & Tidak terjadi heteroskedastisitas \\
INF & 1,00 & Tidak terjadi heteroskedastisitas \\
BNK & 1,00 & Tidak terjadi heteroskedastisitas \\
BMR & 1,00 & Tidak terjadi heteroskedastisitas \\
\hline
\end{tabular}

\section{f. Uji Normalitas}

Uji normalitas digunakan untuk mengetahui apakah datadata yang dikumpulkan berdistribusi normal atau tidak (Ghozali, 2016). Untuk melakukan uji normalitas dapat menggunakan kolmogorov-smirnov.

\begin{tabular}{llc}
\hline \multicolumn{2}{c}{ One-Sample Kolmogorov-Smirnov Test } \\
\hline $\mathrm{N}$ & \multicolumn{2}{c}{ Unstandardized Residual } \\
\hline Normal Parameters & \multicolumn{2}{c}{ Mean } \\
\cline { 2 - 3 } & Std. Deviation &, 0000000 \\
\hline Most Extreme & Absolute &, 064133182 \\
\cline { 2 - 3 } Differences & Positive &, 039 \\
\cline { 2 - 3 } & Negative &,- 064 \\
\hline Test Statistic & &, 064 \\
\hline Asymp. Sig. (2-tailed) &, $019^{c}$ \\
\hline
\end{tabular}


1) Test distribution is Normal.

2) Calculated from data.

3) Lilliefors Significance Correction.

Berdasarkan hasil diatas diketahui bahwa nilai K-S 0,064 diatas tingkat signifikansi 0,05 sehingga dapat disimpulkan bahwa data terdistribusi normal.

Untuk uji hipothesis menggunakan uji korelasi kanonikal. Berikut hasil uji korelasi kanonikal.

1) Fungsi Kanonikal dan Model Fit

EFFECT .. WITHIN CELLS Regression Multivariate Tests of Significance $(S=5, M=4, N=109$ )

$\begin{array}{lll}\text { Test Name } & \text { Value } & \text { Sig. of F } \\ \text { Pillais } & 1,99850 & , 000 \\ \text { Hotellings } & 8,79307 & , 000 \\ \text { Wilks } & , 02960 & , 000 \\ \text { Roys } & , 87202 & \end{array}$

Berdasarkan tabel anova diatas menunjukkan bahwa wilks lambda menunjukkan signifikansi dibawah 0,05, sehingga dapat disimpulkan bahwa korelasi kanonikal signifikan.

Eigenvalues and Cannonical Corelation

$\begin{array}{ccc}\text { Root No. } & \text { Canon Cor. } & \text { Sq. Cor } \\ 1 & , 93382 & , 87202 \\ 2 & , 71163 & , 50642 \\ 3 & , 65076 & , 42348 \\ 4 & , 34238 & , 11722 \\ 5 & , 28170 & , 07935\end{array}$

Dimension Reduction Analysis

Roots Wilks L. Sig. of F

1 TO 5 ,000

2 TO 5 , 23127

3 TO 5 , 4600

4 TO 5 , 801

5 TO 5 , 92065 
Berdasarkan ahsil uji diatas diketahui bahwa fungsi kanonikal 1 dengan nilai korelasi kanonikal sebesar 87,20\% dengan tingkat signifikansi 0,00.fungsi kanonikal 2 menunjukkan nilai korelasi kanonikal sebesar 50, 642 dengan tingkat signifikansi 0,00.. Fungsi kanonikal 3 menunjukkan nilai korelasi kanonikal sebesar 42,248\% dengan tingkat signifikansi 0,00. Fungsi kanonikal 4 menunjukkan nilai korelasi kanonikal sebesar 11,722\% dengan tingkat signifikansi 0,01. Fungsi kanonikal 5 menunjukkan nilai korelasi kanonikal sebesar $7,935 \% \%$. dengan tingkat signifikansi 0,042 berdasarkan hasil ola data tersebut maka fungsi kanonikal tersebut dapat dianalisis lebih lanjut

2) Kanonikal Weight

Standardized canonical coefficients for DEPENDENT variables function No.

$\begin{array}{lccccc}\text { Variable } & 1 & 2 & 3 & 4 & 5 \\ \text { ROA } & , 998 & -, 036 & , 269 & -, 192 & -, 054 \\ \text { ROE } & -, 193 & -, 189 & -, 975 & -, 315 & 1,521 \\ \text { BPTPTA } & , 231 & -, 022 & -, 253 & , 467 & -, 697 \\ \text { NPF } & , 011 & , 009 & , 398 & 1,018 & , 534 \\ \text { REO } & , 008 & 1,075 & , 170 & -, 477 & -, 254\end{array}$

Standardized canonical coefficients for COVARIATES CAN. VAR.

$\begin{array}{lccccc}\text { COVARIATE } & 1 & 2 & 3 & 4 & 5 \\ \text { PSR } & , 269 & -, 159 & , 579 & , 896 & 2,558 \\ \text { ZPR } & , 544 & -, 553 & -6,935 & -, 044 & -, 299 \\ \text { EDR } & -, 696 & , 462 & 6,477 & , 778 & 1,586 \\ \text { KAP } & -, 023 & , 277 & , 047 & -, 217 & -, 159 \\ \text { ASBR } & -, 169 & , 078 & , 038 & , 577 & 1,112 \\ \text { CR } & -, 113 & -, 114 & -, 392 & -, 001 & -, 517 \\ \text { RND } & , 062 & , 960 & , 041 & -, 210 & -, 125 \\ \text { CSR } & -, 017 & -, 107 & , 112 & -, 429 & , 045 \\ \text { MWR } & -, 039 & , 714 & , 277 & , 195 & -, 004 \\ \text { SMWR } & , 858 & -, 191 & -, 162 & , 641 & , 408 \\ \text { GDP } & , 030 & -, 208 & , 053 & 2,162 & -1,913 \\ \text { INF } & -, 098 & -, 029 & -, 094 & , 007 & -, 034 \\ \text { BNK } & -, 067 & , 008 & -, 328 & -, 244 & -, 989 \\ \text { BMR } & , 208 & , 109 & , 474 & , 350 & , 407\end{array}$


Untuk fungsi 1 pada dependen variabel terdapat satu angka tertinggi yaitu ROA sedangkan untuk variabel independen angka korelasi diatas 0,5 yaitu ZPR DAN SMWR

Canonical Loading

Correlations between COVARIATES and canonical variables CAN. VAR.

$\begin{array}{lccccc}\text { Covariate } & 1 & 2 & 3 & 4 & 5 \\ \text { PSR } & , 345 & , 115 & , 245 & , 061 & -, 038 \\ \text { ZPR } & -, 315 & , 051 & , 010 & , 178 & , 034 \\ \text { EDR } & -, 376 & , 045 & , 093 & , 193 & , 028 \\ \text { KAP } & , 232 & , 382 & , 305 & , 088 & -, 074 \\ \text { ASBR } & , 203 & , 163 & , 301 & , 438 & -, 559 \\ \text { CR } & , 019 & , 136 & -, 275 & -, 073 & -, 203 \\ \text { RND } & -, 046 & , 861 & -, 321 & -, 089 & , 011 \\ \text { CSR } & , 151 & -, 213 & , 368 & -, 260 & , 124 \\ \text { MWR } & , 359 & , 160 & , 270 & -, 009 & -, 068 \\ \text { SMWR } & , 956 & , 007 & -, 021 & , 126 & -, 151 \\ \text { GDP } & , 359 & , 032 & , 184 & -, 174 & -, 169 \\ \text { INF } & , 038 & -, 051 & -, 101 & , 160 & -, 209 \\ \text { BNK } & , 273 & -, 309 & , 389 & , 179 & -, 108 \\ \text { BMR } & , 332 & -, 286 & , 413 & , 074 & -, 034\end{array}$

untuk variabel independen angka korelasi diatas 0,5 yaitu SMWR

Berdasarkan hasil canonical weight dan canonical loading dapat disimpulkan bahwa terdapat hubungan signifikan antara performance value, financial value, strategic value dan makroeconomi value. Dari 14 variabel independen hanya variabel ZPR (zakat Performance Ratio) dan SMWR (Shohibul Maal Wealth Ratio) yang memiliki hubungan paling erat.

Penelitian ini mencoba untuk menngklasifikasikan faktorfaktor pemicu (drivers) yang mempengaruhi kinerja bank syariah dengan mengidentifikasi faktor-faktor pemicu (drivers) baik dari dalam (internal) dan dari luar (eksternal). Drivers internal diidentifikasi dengan menggunakan finansial driver dan strategic driver. Menurut Tiwari (2015), drivers dapat digunakan untuk menciptakan nilai bagi perusahaan dengan menemukan keunikankeunikan sebagai penciri perusahaan melalui proses indentifikasi 
drivers yang yang berpengaruh terhadap peningkatan nilai bagi para stakeholders. Penciptaan nilai bagi stakehorders sangtlah penting dalam rangka untuk penghimpunan dana bagi perusahaan.

Ketepatan proses identifikasi drivers akan memberikan keuntungan bagi perusahaan untuk memetakkan nilai-nilai keunggulan yang dapat meningkatkan kesan dan harapan bagi para stakeholders terhadap perusahaan. Aspek finansial, strategi dan makro ekonomi tidak dapat dipisahkan ketika kita membahas mengenai drivers performance value bagi bank syariah. Ketiga hal terssebut saling berkaitan dalam meningkatkan kinerja bank syariah dengan peran masing-masing

Hasil pengujian hipothesis pertama menunjukkan bahwa terdapat hubungan antara financial value terhadap kinerja bank syariah.

Hasil pengujian hipotesis kedua menunjukkan bahwa terdapat hubunan antara strategic value driver dengan kinerja bank syariahdengan arah hubungan positif. Startegic value drivers ini berhubungan dengan nilai-nilai strategik yang diambil oleh perusahaan dalam rangka untuk meningkatkan kinerja perbankan shariah. Nilai strategik ini berhubungan dengan Strategic value drivers ini merupakan langkah yang dipilih perusahaan dalam rangka membangun dan mengembangkan perusahaan dengan serangkai kebijakan yang diambil oleh manajemen dalam rangka menciptakan nilai atau persepsi bagi para investor. Ketepatan strategi yang diambil oleh perusahaan pada akhirnya akan berdampak pada penciptaan nilai perusahaan

Hasil pengujian hipotesis ketiga menunjukkan bahwa terdapat hubungan antara macroekonomi driver dengan kinerja bank syariah. Kegiatan makro ekonomi yang dilakukan oleh suatu negara akan berdampak pada kebijakan yang diambil oleh pemerintah dalam hal ini kebiajakan yang berkaitan dengan kebijakan moneter yang diambil. Kebijakan moneter yang diambil oleh pemerintah akan berdampak pada laju perkembangan perbankan pada umumnya sehingga kinerja bank syariah akan sensitif terhadap laju perkembangan makro okonomi suatu negara. faktor makro 
ekonomi perlu untuk diidentifikasi untuk mengevaluasi kinerja pada perbankan shariah.

\section{E. Simpulan}

Tujuan penelitian ini adalah untuk mengidentifikasi faktorfaktor pemicu (drivers) yang berhubungan dengan kinerja bank syariah. Dalam penelitian ini mengidentifikasi tiga (3) drivers yang diduga mempengaruhi kinerja bank syariah yaitu financial value, strategic value dan macroeconomic. Dalam peelitian ini hanya dua variabel yang memiliki kaitan erat dengan kinerja yaitu ZPR (zakat Performance Ratio) dan SMWR (Shohibul Maal Wealth Ratio) yang memiliki hubungan paling erat.

penelitian ini memeiliki berbagai keterbatasan, untuk penelitian selanjutnya perlu adanya proses identifikasi yang lebih luas mengenai faktor-faktor yang berhubungan dengan kinerja bank shariah di Indonesia serta perlunya menguji kointegrasi antara variabel tersebut untuk memperoleh gambaran efek jangka panjang dari masing-masing variabel yang berhubungan dengan kinerja bank syariah 


\section{DAFTAR PUSTAKA}

Al Kayed, Lama Tarek., Zain, harifah Raihan Syed Mohd dan Duasa, Jarita. 2014. The relationship between capital structure and performance of Islamic banks. Journal of Islamic Accounting and Business Research, Vol. 5 Iss 2 pp. 158 - 181. http:/ / dx.doi. org/10.1108/JIABR-04-2012-0024

Asutay, Mehmed \& Harningtyas, Astrid, Fiona. 2015. Developing Maqasid al-Shari'ah Index to Evaluate Social Performance of Islamic Banks: A Conceptual and Empirical. International Journal of Islamic Economics and Finance Studies, 2015, Year:1, Volume:1, Number:1.

Bank Indonesia. Statistik Perbankan Syariah. http://www.bi.go.id/ id/statistik/perbankan/syariah. Diakses tanggal 18 Maret 2016.

Bank Indonesia. Peraturan Bank Indonesia no. 14/6/PBI/2012. Uji Kemampuan dan Kepatutan Bank Umum Syariah dan Unit Usaha Syariah.

Bank Indonesia. Peraturan Bank Indonesia nomor 13/23/PBI/ 2011. Penerapan Manajemen Risiko bagi Bank Umum Syariah dan Unit Usaha Syariah.

Bank Indonesia. Peraturan Bank Indonesia Nomor 14/18/PBI/ 2012. Kewajiban Penyediaan Modal Minimum.

Bank Indonesia. Surat Edaran no. 15/26/DPBS. Pelaksanaan Pedoman Akuntansi Perbankan Syariah.

Capra, M. Umer \& Ahmed, Habib. 2002. Corporate Governance in Islamic FinancialInstitution. Jedah: IRTI-IDB.

Ghozali, Imam. 2016. Aplikasi Analisis Multivariat dengan Program IBM SPSS 23. Semarang. Badan Penerbit Universitas Diponegoro

Hameed, Shahul, Ade Wirman, Bakhtiar Alrazi, Mohd Nazli bin Mohamed Nor and Sigit Pramono. (2004). Alternative Disclosure \& Performance Measures for Islamic Banks. Kuala Lumpur: International Islamic University Malaysia. 
H.M, Jogiyanto. 2008. Teori Portofolio dan Analisis Investasi. Edisi II, BPFE-. UGM. Yogyakarta

Ittner, C. D., \& Larcker, D. F. 2001. Assessing Empirical Research in Managerial Accounting: A Value Based Management Perspective. Journal of Accounting \& Economics, 32 (12), 349 10. http:/ / dx.doi.org/10.1016/S0165-4101(01)00026-X.

Kazlauskiene V., \&Christauskas, C. 2008. Business Valuation Model Based on the Analysis of Business Value Drivers. Engineering Economics, 57 (2).

Mohammed, Mustafa Omar, Dzuljastri Abdul Razak and Fauziah Md Taib. 2008. The Performance Measures of Islamic Banking Based on the Maqasid Framework. Paper of IIUM International Accounting Conference (INTAC IV) held at Putra Jaya Marroitt.

Undang Undang Negara Republik Indonesia No.10 tahun 1998. Tentang Perbankan

Undang-Undang Negara Republik Indonesia No.21 tahun 2008. tentang Perbankan syariah

Pellegrina, Lucia Dalla. 2012. Does capitalization enhance efficient risk undertaking?. Accounting Research Journal, Vol. 25 Iss 3 pp. 185-207. http://dx.doi.org/10.1108/10309611211290167.

Siddiqui, Anjum. 2008. Financial contracts, risk and performance of Islamic banking. Managerial Finance, Vol. 34 No. 10, 2008, pp. 680-694. DOI 10.1108/03074350810891001.

Scott, William R. 1997. Financial Accounting Theory.Prentice Hall. Inc.

Scott, William R. 2000. Financial Accounting Theory, $2^{\text {nd }}$. Prentice Hall Canada. Inc

Tiwari, Ranjit. 2015. Drivers of Firm's Value: Panel Data Evidence from Indian Manufacturing Industry. Asian Journal of Finance E Accounting 2015, Vol. 7, No. 2. http://dx.doi.org/10.5296/ ajfa.v7i2.7243.

Turner, R. 1998. Projects for Shareholder Value: The Influence of Project Performance Parameters at different Financial Ratios. Project Management, 4 (1), 70-74 